\title{
Penal Reforms, Penal Ideology, and Vagrants in Norway ca. 1900
}

\author{
Prevention through \\ Treatment or Incapacitation?
}

FRODE ULVUND*

\section{$1 \quad$ Introduction $^{1}$}

The Criminal Code of 1902 was in effect until October 2015, and has consequently framed Norwegian criminal law for more than a Century. The code was originally part of a larger penal reform and pivotal in Norwegian social- and criminal policy-making at the turn of the century. The Law Professor Francis Hagerup (1853-1921) emphasised the year before the code was adopted that the reform did not only include the Criminal Code, but a number of bills which were interrelated. ${ }^{2}$ Hagerup mentioned three domains that deserved special attention: children, vagrancy and alcoholism. These domains corresponded to two other major legal reforms at the time: the Treatment of Neglected Children Act (1896) and the Vagrancy, Begging and Drunkenness Act (1900). Professor and Director General of Public Prosecution Bernhard Getz (1850-1901), the main architect behind the

Professor in History, Department of Archeology, History, Cultural Studies and Religion, University of Bergen.

1 Parts of this article has been published in earlier versions, partly in Norwegian in Ulvund, Dele af ét System, Forebygging gjennom behandling eller uskadeleggjering i strafferettsreformene rundt 1900 in Straff, lov, historie: historiske perspektiver på straffeloven av 1902, eds. Flaatten \& Heivoll (Akademisk Forlag 2014), and partly in Ulvund, A deterrent to vagabonds, lazy persons and promiscuous individuals: Control and Discretion in the Norwegian Workhouse System, 1845-1907, in 16 Crime, History \& Societies (2012), issue 2.

$2 \quad$ Forhandlinger ved Den norske kriminalistforenings sjette møde i januar 1901 (Aschehoug 1901) p. 3. 
reforms, also emphasised the complementary relation between these legal reforms, as he described them all as 'part of one system. ${ }^{3}$

This calls for a closer scrutiny of other elements of the penal reform than the Criminal Code of 1902 itself. This is not only obviously relevant, but even necessary in order to understand the ideology and intended function of the code and the reforms it was an integrated part of. Furthermore, by highlighting the different components of the reform project, with the nexus of discipline and infringement in individual liberties on the one side, and individual care and support on the other, the emerging model of Nordic welfare systems is made visible.

In this article, I will focus on the Vagrancy Act and discuss the role of individual prevention, which the reforms are associated with in general, when it came to vagrants and chronic alcoholics. Before the Vagrancy Act, repressive measures against vagrants and alcoholics were authorised in the Poor Law. The police were vested with a discretionary power to incarcerate suspected vagrants in a workhouse for up to six months, without any legal recourse. Social renovation was the main purpose of such a confinement, which was also used as an instrument to incapacitate people suspected for unproven criminal acts. According to the Vagrancy Act, able-bodied persons who were considered as burdens to the public as well as idle persons who were not, but only suspected of regular acts of crime, were subjected to punishment. In addition, beggars, casual drunkards and alcoholics were also targeted. In this sense, the new Vagrancy Act did not differ much from the corresponding articles of the old Poor Law. The new Vagrancy Act of 1900 (in force from 1907) required legal procedures before incarceration, but the length of each sentence was extended significantly, with six years as the maximum.

I will argue that though treatment was an important rhetorical argument when shaping and passing the bill, the main purpose for reforming regulations towards vagrants and alcoholics was still to incapacitate them and to render them harmless. Among the penal reforms, the Vagrancy Act thus represented continuity when it came to purpose, and innovation when it came to procedural rules.

\section{Vagrants between Poor Law and Criminal Code}

In the early nineteenth century in Norway three different institutions were in involved with incarceration: prisons, bridewells (tukthus), and 'slaveries'. The prisons were normally not used for punishment, but as custody houses for those awaiting trial. The bridewells were mixed institutions rooted in the handling of the poor. From the mid-eighteenth century, the bridewells were closely integrated with policies towards the poor. Local authorities were obliged to round up all vagrants and remand them to the nearest bride-

Bernhard Getz quoted in Forhandlinger ved Den norske Kriminalistforenings tredie møde $i$ november 1894 (Aschehoug 1895) pp. 8f. 
well after a trial. In 1789, bridewells became the normal mean of punishment for thefts, thereby shifting its main character from social control to a penal institution. Fortresses in which men served hard labour for six years of more, were labelled 'slaveries' and their inmates were subjected to military command.

With the new Criminal Code in 1842, the bridewells were exclusively used as penal institutions, and they were detached from any connection with the poor laws. Consequently, the opportunity to detain so-called 'unworthy' paupers in bridewells disappeared. However, the government was obviously not willing to abandon this instrument altogether, and allowed local authorities to establish new workhouses, which were founded under the Poor Law of 1845 . The law allowed for the incarceration of convicted beggars; but the most important target was the social residuum among the urban proletariat. With a simple administrative decree, without any involvement from the judicial system, the police were authorised to detain individuals for periods up to six months, if they were known to be idle or alcoholic, and hence suspected to be without legal means of subsistence. The decision was final and there was no opportunity for appeal or legal recourse. Furthermore, until 1894, there was no requirement for the police to provide a formal justification. The only criterion was age, as the detainees had to be at least 15 years of age.

The ability to summarily detain vagrants generated little discussion in the 1840 s, and these powers were virtually uncontested until the 1890s. The parliamentary committee that prepared the Poor Law bill in 1845 did discuss whether it was in violation of the constitution. The Constitutional article 96 stated that no one could be sentenced without having violated the law, and no one could be punished without a court verdict. The committee concluded that detention in a workhouse was not to be regarded as punishment, but as a measure benefitting the inmate as well as the community in which he or she lived. ${ }^{4}$ A committee revising the Poor Law in the late 1850s and early 1860 s expressed some scepticism towards the discretionary powers vested in the local police. However, proposals to place some limitations around these powers were met with fierce resistance among the local authorities and were quickly abandoned by the government. ${ }^{5}$ Only in the final decade of the nineteenth century was the practice seriously questioned, and the procedures revised, as the discretionary practices of the police were to be supervised in retrospect by the Ministry of Justice. The discretionary instrument provided by the Poor Law was in place from 1845 right until 1907, when the new Vagrancy Act entered into force and introduced judicial decisions for such cases. Thus, Norway maintained

4 A recommendation by the standing Church Committee in the Norwegian Parliament dated 9.8.1845, here quoted from Midré, Bot, bedring eller brød?: om bedømming og behandling av sosial nød fra reformasjonen til folketrygden (Universitetsforlaget 1990), p. 101.

$5 \quad$ Ulvund, Byens Udskud. Ein studie av karrierar som innsett i tvangsarbeids- og straffanstaltar i Bergen ca 1850-75, Dr. thesis, (University of Bergen 2002), p. 398. 
discretionary detention against the 'dangerous' poor for a longer period than most other countries. ${ }^{6}$ The workhouse sentence for vagrancy was abolished as late as 1970 .

The experience of being in workhouse detention was very similar to being imprisoned in institutions that applied penal servitude through hard labour, a comparison that was also made by Bernhard Getz when he in 1893 explained that workhouses were 'penal institutions in which people can be detained discretionarily.' The inmates were dressed in workhouse uniforms, locked up, and guarded day and night. The daily routines were similar to those in a prison, as was the type of work. Typical work for male detainees consisted of picking oakum, breaking stones, and of various handicraft production, while spinning, weaving, and household duties were undertaken by the female inmates. Irregular behaviour could lead to disciplinary actions, including by whipping. A major difference between workhouses and penal institutions was that the workhouses did not operate with a classification and separation of inmates - a practice that was increasingly implemented in the penal institutions. Major reforms from the 1850s modernised Norwegian prisons in accordance with the Philadelphia System, and numerous new prisons were erected in the 1860 s based on the principles of isolation and classification. ${ }^{8}$ The criticism towards older prisons was never directed towards workhouses, even though these were similarly organised. The argument was that most workhouse inmates were incorrigible, and therefore cohabitation day and night between inmates caused no further moral contamination.

Numerous reports and witnesses claimed that most male inmates suffered from alcoholism. One example came from the workhouse chaplain in Bergen. He stated in 1880 that the male inmates were in general severely alcoholic and most had a so-called 'weak' character. ${ }^{9}$ As long as they stayed in the workhouse, they remained sober, but once they were back on the street, they fell back into old habits as they were re-exposed to their alcoholic friends. For many, it only took a couple of days before they found themselves arrested and back in the workhouse again. While convicted criminals received some help and financial support upon release from penal institutions, the workhouse inmates received nothing. The consequences were unsuitable lodgings, if any at all, and the company of old drinking-friends as their only social network outside the workhouse. In addition, bad reputation and ailing health from years of alcohol abuse made it difficult for them to find, not to mention retain, any form of work.

6 See Hippel, Verbrechen und Vergehen wider die öffentliche Ordnung (Liebmann 1906), pp. $107 \mathrm{ff}$.

$7 \quad$ Forhandlinger ved den norske kriminalistforenings andet møde i oktober 1893 (Aschehoug 1894), p. 118.

8 See Schaanning, Menneskelaboratoriet. Botsfengslets historie (Scandinavian Academic Press 2007), especially chapter 3.

9 Norwegian National Archives (NNA): Justisdepartementet, Fengselsstyret, Kontor D, Db. L0120/ 3A 115 2/2, 'Tvangsarbeidsanstalter, Bergen 1872-1907'. Innberetning 1880. 
Contemporaries often highlighted the link between alcoholism and petty crime. This is vividly illustrated in a report by a workhouse chaplain. He quoted an inmate's description of his and his friends' routines in the town of Trondheim: 'When we embark on a drinking binge we keep on till all the money is gone; then we pawn our clothes, and then finally we steal for drinks. ${ }^{10}$ The majority of male inmates also received at least one criminal conviction at some point in their life, most often because of theft or disorderly and violent behaviour. ${ }^{11} \mathrm{~A}$ number of individuals were also locked up in workhouses for being suspected of criminal acts, where the police were unable to prove guilt. One example concerned the prostitute Nille Nielsdatter. The police journal tells us that she was arrested in Bergen in March 1857 under suspicion of having committed theft. At the time of her arrest, she was intoxicated. She was released the following day on account of inconclusive evidence, but was instead detained in the local workhouse for six months. ${ }^{12}$ Another example was Johan Mikkelsen, who was arrested in 1858 under suspicion of burglary. He was also released due to a lack of evidence. However, because he was without financial means, clothes, or permanent work, he was sent to the workhouse for six months. ${ }^{13}$ Evidence suggests that this reflects a form of punishment in cases where the police was convinced of guilt, but were unable to prove the criminal act in court.

Detention in workhouses on the basis of discretionary police decrees without involvement from the judiciary and legal system, served a multiplicity of functions. This is the reason why the practice remained largely uncontroversial for so long. Detention was a flexible solution for the police to intervene against the so-called 'dangerous classes' and the workhouse inmates were regarded both by the police and by the public as outcasts of society, even ranking below most criminals. Prejudices against them were often worse than those faced by criminals, thus leading to a situation that was not so different from Eric Monkkonen's depiction of the poorhouse in Columbus, Ohio, in the second half of the nineteenth century. Monkkonen describes the paupers as being at the very bottom of the 'dangerous class' within the United States. ${ }^{14}$ The Poor Law provided a very efficient instrument to cleanse the streets of troublemakers and habitual criminals whose criminal acts were difficult to prove in court. Furthermore, the workhouse provided an opportunity for neighbours and families to shift the responsibility for disorderly individuals to the authorities. Finally, the workhouse constituted a last resort for destitute paupers.

10 Hval, Om forbryderens vilkår, Nordisk Tidsskrift for Fongselsvosen og øvrige penitentiore institutioner, (1884), p. 196.

11 See Ulvund 2002, pp. 365ff.

12 Bergen State Archive (BSA), Politimesteren i Bergen, 'Forretningsjournal 'No.1, 1856-1857, 11.3.1857.

13 BSA, Politimesteren i Bergen, 'Forretningsjournal' No.2, 1858-1860, 1.5.1858.

14 Monkkonen, The dangerous class: crime and poverty in Columbus, Ohio, 1860-1885, (Harvard University Press 1975), pp. 155ff. 
Only towards the end of the nineteenth century was this practice seriously questioned, leading to the abolition of the completely unsupervised discretionary workhouse system. However, the motives behind this change were not based on concerns for the alcoholics and vagrants who were subjected to detention. Rather, it was a professional project initiated by Bernhard Getz to adapt the legislation to comply with the principles on the rule of law and counteract the duality between protection of civil liberties and the need for effective public order policing which prevailed in contemporary liberal jurisprudence. Getz argued very strongly against the manner in which forced labour was imposed under the Poor Law. He found it to be inconsistent and incompatible with the principles of a constitutional state governed by law. The discretionary power of the police, he declared, was 'a serious breach with the most important principles of the rule of law' to the extent that it had to be changed even without awaiting a new Criminal Code. ${ }^{15}$ In the draft of the Vagrancy Bill of 1894, Getz and the Penal Reform Commission he was heading responded to the objections against the discretionary power of the police. The draft concluded that the difference between forced labour in a workhouse and the regular punishment of hard labour 'was so indistinguishable, that the constitutional principle according to which no one could be punished without a conviction was easily evaded, unless the same requirement to due legal process was also applied to forced labour in workhouses. ${ }^{16}$ In addition, Getz argued that many cases of detentions not only violated the Constitution, but were also in breach of the 1854 act, which repealed the general obligation to be in employment. This act stated that no one could be punished or treated as a vagrant if he or she subsisted without begging or being a burden to the public purse. According to Getz, this point was often not considered when the police decreed detention.

Getz' arguments caused important changes as early as 1894. First, the police was instructed to provide accurate information as justification for each detention, and to give suspected vagrants the opportunity to explain themselves. Any decision to detain them had to be protocolled with a detailed justification. ${ }^{17}$ Shortly afterwards, the Ministry of Justice stated that drunkenness and idleness did not alone constitute a sufficient reason for detention; instead the suspected vagrant had to be without legal means of subsistence. Similarly to Getz, the Ministry also claimed that this distinction had often been ignored. They insisted that a precondition for detention should be whether the suspect or his family were to be considered as a burden on society, either by receiving poor relief or by begging for a living. ${ }^{18}$

15 Getz, Udkast til almindelig borgerlig straffelov for kongeriget Norge (Kristiania 1893) p. 119, footnote 1 .

16 Straffelovkommissionen (Kristiania 1894) p. 16.

17 Resolution from the Crown Prince 7.5.1894, in Love, Resolutioner, Reglementer, Instruxer, Skrivelser m.v. vedkommende Fangselsvoesenet 1814-97 (Kristiania 1898).

18 Circular from Department of Justice 24.5.1894, in Love, Resolutioner, Reglementer, Instruxer, Skrivelser m.v. vedkommende Fongselsvoesenet 1814-97 (Kristiania 1898). 
Civil servants in the Ministry of Justice thoroughly scrutinised in retrospect the decrees issued by the police and their justifications, and often instructed the local police to improve the exactness of the justifications. The police in Bergen in western Norway was prescribed to do so as late as 1904 , as the Ministry complained that previous practices were too general and did not convey sufficient information regarding the basis on which the police decided to detain people. ${ }^{19}$ Obviously, the central authorities had motives other than a desire to improve the civil rights of the inmates when supervising decrees of workhouse detentions. They suspected that the municipal authorities were shifting the expenses of poor relief from the local taxpayers to the central authorities, as the latter were partly financing workhouse detentions. ${ }^{20}$ This was especially the case when the local police detained old people whom the Ministry assumed might not be able-bodied. These were not subjected to forced labour, but granted regular poor relief.

In many respects, all Scandinavian countries experienced similar developments with regard to social policy from the end of the nineteenth century, as they gradually evolved into welfare states. This process started in the latter part of the nineteenth century; although at first the scope of welfare institutions was limited. During the initial stages of institutions that later evolved into 'the welfare state', it was considered important to develop effective instruments to distinguish between those worthy of receiving public relief and those who were not; and the Scandinavian countries all devised their legislation to reflect this purpose during this period. ${ }^{21}$

Industrialisation and the transformation of the labour market, with its emphasis on mobile, wage-earning labour, inevitably led to a reconceptualisation of unemployment and idleness, since unemployment was considered fundamentally different from being unwilling to work. The free movement of labour was encouraged and older laws obstructing such mobility across regions were liberalised or repealed in order to create national labour markets. Because workers increasingly depended on wages and were vulnerable to industrial economic cycles, the question of how to deal with involuntary unemployment became increasingly pressing. As the suffrage expanded to the wage-earning classes, this was also important in order to facilitate their social integration as well as to anchor their political loyalty to what were then emerging nation-states within the international state system. Concurrently, the image of an increasing urban residuum inflicting great social and moral harm to society at large was constructed, leading to widespread demands for heavy-handed measures against those regarded as unwilling to work.

19 NNA: Justisdepartementet, Fengselsstyret, Kontor D, Db. L0178/ 3A 115 3/1 'Opgave over innsatte i tvangsarb. anst. II 1904', JD.JNo 1560/1904.

20 NNA: S-1043 Justisdepartementet, Fengselsstyret D del 1, L0158 'Oppgave over innsatte i tvangsarbeidsanstaltene 1894 - 1895’ 3A 1152/6, The Departementet's review of detentions from Kristiania 4. quarter 1894.

$21 \quad$ Ulvund 2012 op.cit. 
As a consequence, it became essential to distinguish between different types of able-bodied individuals without employment. The aim was to facilitate and assist 'honest' people, who were looking for work, without pauperising them, and to discipline and control the remaining 'hard-core' of presumed professional vagrants. The template was the German network of work stations (Wanderarbeitsstätten or Natural-Verpflegungsstationen), where migrants looking for work were provided with shelter as long as they followed a strict itinerary and subjected themselves to a work test. ${ }^{22}$ The English Casual Wards had a similar purpose. This transition helped to bring about legal reforms that distinguished clearly between involuntary unemployment and vagrancy. In Norway, this distinction was provided for under the new Vagrancy Act.

\section{Penal differentiation}

The penal reforms were initiated with the appointment of a Penal Reform Commission in 1885, with Professor Bernhard Getz - Director General of Public Prosecution from 1889 - as the driving force and main engineer of legal proposals. Getz explained in a meeting at the Norwegian Criminalist Association in 1894 that the goal, and not the means, constituted the main principles of the penal reforms promoted by the commission. ${ }^{23}$ The means, or the punishments, were subordinate to the objective of the criminal policy; to counteract crime and undesirable behaviour. In order to achieve this, Getz explained, other instruments than punishments had to be implemented in many cases. Most important were different mechanisms of separation and differentiation towards criminals in general, and towards vagrants and children especially. When identification and segregation was achieved, different means could be applied outside the penal system, depending on necessity and requirements among the different target groups.

By shifting focus from the act to the offender, attention would also have to be given to the social context of the offender. Thus, penal policy was closely connected to a more general social policy directed to counteract numerous ills of society. Explanations of crime were not only to be rooted in the inferior moral standard of the offender, but also understood as provoked by negative aspects in the community in general, or the social background of the perpetrator. This was an important reason as to why the Penal Reform Commission reinforced instruments outside the Criminal Code. Getz explained that the commission was preoccupied with the treatment of social ills, which had particularly infused crime, such as the neglect of children, vagrancy and drunkenness. Treatment was partly to be achieved through punishment, but equally often, and partly exclusively,

22 Frohman, Poor relief and welfare in Germany from the Reformation to World War I (Cambridge University Press 2008).

23. Forhandlinger ved Den norske Kriminalistforenings tredie møde i november 1894 (Aschehoug 1895) p. 6. 
through other means in order to 'root out the ills' and 'block the springs, from which the infectious matter unfolded. ${ }^{24}$ Prevention was referred to as a better strategy than repression, and the idea was to prevent individuals from ending in a situation in which punishment was required. The subtraction of social domains such as children, vagrancy and intoxication from the sphere of the Criminal Code was thus an important instrument.

To understand this shift, it is crucial to emphasise to role of science and the process of professionalisation which was ongoing at the time. Improvements in medicine, statistics and sociology all contributed largely to define social ills and to the set the agenda for how social questions were discussed. A new science - criminology - evolved, especially following the Italian Cesare Lombroso's publication of L'uomo delinquente ('The Criminal Man') in 1876. Lombroso was a professor of psychiatry, and David Garland ties the birth of criminology to three factors: the qualitative and quantitative improvements in statistics, advances in psychiatry and the availability of prisons as scientific laboratories for criminological research. ${ }^{25}$

International conferences and the establishment of associations in criminal law were a result of increased scientific interest in all things criminal. Starting in 1885, international penal conferences were regularly held addressing different aspects of criminal law under the influence of scientific advances. ${ }^{26}$ The International Union of Criminal Law was established in 1889 by Law Professors Franz von Liszt, Gerhard Anton van Hamel and Adolphe Prins, which arranged meetings almost annually. In these, Getz soon became an important participant. ${ }^{27}$ The fact that the third conference was held in Oslo in 1891 illuminates the position of Norwegian legal professors within the Union. ${ }^{28}$ The Union addressed a number of penal questions. For instance, the topic at one meeting in Oslo was

24 Forhandlinger ved Den norske Kriminalistforenings tredie møde i november 1894 (Aschehoug 1895) pp. 7 ff.

25 Garland, The Criminal and His Science: A Critical Account of the Formation of Criminology at the End of the Nineteenth Century, in 25 The British Journal of Criminology, (No. 2, April 1985), p. 112.

26 Skålevåg, Tilregnelighet, (Pax forlag, forthcoming 2016), p. 85.

$27 \quad$ The International Union of Criminal Law existed between 1889 and 1933 and was called Die Internationale Kriminalistische Vereinigung in Germany and L'Union Internationale de Droit Penal in France.

28 The importance of national members for choosing congress locations is emphasized by Sylvia Kesper-Biermann, with reference to the Oslo congress in 1891 in 'Die Internationale Kriminalistische Verinigung. Zum Verhältnis von Wissenschaftsbeziehungen und Politik im Strafrecht 1889-1932', in Die Internationalisierung von Strafrechtswissenschaft und Kriminalpolitik (1870-1930). Deutschland im Vergleich, eds. Kesper-Biermann \& Overath (Bwv BerlinerWissenschaft 2007), p. 87. 
'The Incorrigible', two years later the Union deliberated over 'the criminal-sociological and criminal-anthropological influence on penal law' at the Paris conference. ${ }^{29}$

The Norwegian Criminalist Association was founded in 1892 by the Norwegian members of the international union. ${ }^{30}$ The first meeting gathered 124 representatives from a number of sciences and professions. The association created a public arena in which current international penal topics and their social implications could be addressed within a Norwegian context. Not only were social ills identified and defined, but a number of counter-measures were discussed and carved out. This contributed to a more scientific approach towards the individual criminal as well as towards social policy in general. Not unlike the medical science, which focused on patients and treatments to cure them physically or mentally, the penal system focused on offenders and their moral treatment. The similarities in approaches between the two branches of science resulted in similar discursive practises as especially the penal discourse was conflated with the medical.

How the penal reforms were motivated, and how they were evaluated in their aftermath, raises important questions regarding penal ideology. Prevention was rhetorically important in justifying all the reforms, but the emphasis on treatment, as opposed to the ability to render the subjects harmless, differed from act to act. Prior to the adoption of the Children's Act, treatment was especially promoted as its main function, though not exclusively. In the preparation of the Vagrancy Act, the societal right to protect itself from the danger of vagrancy and alcoholism was accentuated. But even the Vagrancy Act was connected to a medical discourse of treatment.

From 1887 and on, the Penal Reform Commission suggested and was able to integrate elements of individual prevention with the introduction of waivers of prosecution and deference of sentences. ${ }^{31}$ The purpose was to prevent young offenders from being exposed to unfavourable prison cultures. The 1902 Criminal Code introduced extended incarcerations, in which the judiciary was authorised to sentence presumed dangerous offenders to incarceration extending the normal punishment for the violation for as much as three times, limited to 15 years longer than regular punishment. Thus, penal attention was to be directed towards the offenders who were considered dangerous based on a scientific assessment of criminal disposition and societal danger. This was even more relevant in the case of children, vagrants and alcoholics, who were detached from the Criminal Code and the regular criminal procedure, and who were also subjected to a specific process and sanction.

29 Kitzinger, Die Internationale Kriminalistische Vereinigung. Betrachtungen über ihr Wesen und ihre bisherige Wirksamkeit (Beck 1905), p. 77 and Judge Hausmanns quoted in Forhandlinger ved Den norske Kriminalistforenings tredie møde i 1894 (Aschehoug 1895) pp. 105 ff.

30 Andenæs, Den Norske Kriminalistforening gjennom 75 år, in Nordisk tidsskrift for kriminalvidenskab (1968), p. 1.

31 Code of Criminal Procedure 1887-07-01, (Lov om Rettergangsmaaden i Straffesager), $₫ 85$. 
The Children's Act granted a board of guardians far reaching power over boys under 14 years of age and girls under 16 years of age. ${ }^{32}$ With discretions, the board could remove children from their homes and place them in educational institutions for years. Such sanctions also applied for pre-criminal children, i.e. children not convicted for any criminal offenses, but who were considered prone to illegal activities. Thus, young, un-convicted children were forcefully removed from local communities and parents who were considered to be unfavourable. This was a proactive intervention intended to stamp down criminal careers by rooting out criminal tendencies in its infancy, as Getz explained.

The first draft of the criminal code from 1893 included articles on vagrancy and alcoholism and introduced a legal procedure prior to detention. At the Criminalist Association's meeting the same year, Legal Historian Ebbe Hertzberg (1847-1912) was the keynote speaker in a discussion on the topic of vagrancy. He emphasised the society's right to protect itself against vagrancy. ${ }^{33}$ As a result, Hertzberg argued that the procedures for detaining vagrants should facilitate the purpose of incapacitation. In his opinion, legal procedures were undesirable. He argued that vagrants needed extended incarceration, in order to facilitate 'real personal improvements and in order to liberate society against the inconveniences and danger of vagrants. ${ }^{34}$ But Hertzberg was not oblivious to the fact that extended detentions for vagrancy were not in compliance with the principle of proportionality. He feared that the judiciary would hand down lenient sentences, and thus counteract the intention to impose discipline and safeguard society. Consequently, he argued that the detention of vagrants should be regulated outside the criminal code and not be labelled as punishment, but as forced support or help. Thus, detentions for years could be justified without legal recourse.

The articles on vagrancy and drunkenness were separated from the draft Criminal Code the following year and promoted as a separate Bill on Vagrancy, Begging, Drunkenness and Workhouses by Bernhard Getz. The separation reflected the thought that the new regulations were so important that there was not time to wait for the complete revision of the criminal code. Getz explained that the separation was a practical solution, not a question of principle. ${ }^{35} \mathrm{~A}$ precondition for Getz was that the responsibility for the prevention of crime was not pulverised and dissipated between different ministries and standing parliamentary committees, but that it was considered 'all part of one system.

32 Act 1896-07-06 on the treatment of neglected children (Lov om Behandling af forsømte Børn).

33 Forhandlinger ved Den Norske Kriminalistforenings andet møde i oktober 1893 (Aschehoug 1894) pp. $87 \mathrm{ff}$.

$34 \quad$ Forhandlinger ved Den Norske Kriminalistforenings andet møde i oktober 1893 (Aschehoug 1894) pp. $110 \mathrm{ff}$.

35 Bernhard Getz in Forhandlinger ved Den norske Kriminalistforenings tredie møde $i$ november 1894 (Aschehoug 1895) pp. 8 ff. 
Regardless of which law these regulations were incorporated into, sanctions against vagrancy would no longer formally be part of the policy towards poor and paupers, but a part of penal policy.

The penal reforms were thus characterised by penal differentiation, accommodated to the individual qualities of those subjected to sanction. Classifications based on presumed societal danger, disciplinary susceptibility, and probability of recidivism, decided which and how penal instruments should be applied. The focus on the offender, and its potential for recidivism, illustrates a paradox and a sphere of conflict; the society's right to defend itself on one side and civil rights and care for the individual on the other. In this border zone, coercion often goes hand in hand with solicitude, and the dividing line between repression and care may be blurred. As a consequence, the motives behind the Vagrancy Act were described using rhetoric related both to treatment and care as well as repressive rehabilitation.

\section{Treat or incapacitate vagrants?}

Bernhard Getz juggled among a repertoire of discourses when he discussed penal reforms. It seems that he consciously chose discursive strategies depending on what he addressed, and whom he addressed. When addressing juvenile crime and drafting the Children's Act, he emphasised elements of treatment and the positive influence of intervention, and downplayed the need to protect society against disobedient and criminally prone children. Children were conveyed as victims in need of rescue. A rhetorical emphasis on treatment was definitely present when he discussed vagrancy and intoxication as well, but a discourse in which society (and not the alcoholic vagrant) was the victim, was nevertheless more present. This was probably a deliberate strategy to facilitate the professional and political process of pushing the reforms through. Getz himself explained at the Criminalist Associations' meeting in 1894 that he had moderated his draft for the Vagrancy Bill because he feared opposition, especially in parliament. ${ }^{36}$

In the Vagrancy Bill, the aspect of treatment was most visible in the articles concerning intoxication. These would also turn out to be the most important articles for detaining men when the act entered into force after $1907 .{ }^{37}$ Curative institutions were mentioned as an alternative to workhouses for habitual drinkers. The Act on Prisons and Workhouses (1900), prepared by Getz and the Penal Reform Commission, also presup-

36 Forhandlinger ved Den norske Kriminalistforenings tredie møde i november 1894 (Aschehoug 1895) p. 79.

37 In the period 1907-1913, i.e. after the Vagrancy Act came to force, 81 percent of men were detained pursuant to the articles regulating drunkenness, and only 16 percent were detained pursuant to articles regulating vagrancy. For women it was the opposite as 56 percent were detained because of vagrancy and 42 percent because of drunkenness. Stortingets forhandlinger (1914): Ot. Prp. 14. table p. 3. 
posed that the state established a separate institution for habitual alcoholics who needed 'special treatment. ${ }^{38}$ This reflected new understandings of drunkenness. The idea that repetitive drunkenness was a result of a moral failure was at least partly replaced by a medical explanation of alcoholism, in which the medical concept 'chronic alcoholism' had been introduced in 1849 by the Swedish doctor Magnus Huss (1807-1890). As a result, this brought about the idea that alcoholism was an illness that could and should be treated, like other medical afflictions.

The Penal Reform Commission clearly expressed an opinion that alcoholism was a disease and stated that ordinary punishment would achieve little for this group. As a result, the Commission suggested forced hospitalisation for alcoholics. ${ }^{39}$ Still, early on, objections were conveyed that the draft did not distinguish clearly enough between those who were occasionally intoxicated and should be punished for public drunkenness, and the chronic alcoholics who should receive medical treatment. ${ }^{40}$

Though alcoholism came to be regarded as a disease, also by the legal profession, the suggested curative instruments demonstrated a somewhat half-hearted faith in the prospects of treatment. Though the bill allowed the state to establish curative institutions, this was not instructed as obligatory. ${ }^{41}$ It was regarded sufficient that existing workhouses be arranged with separate wards having medical functions. How treatment was supposed to be offered, medically or otherwise, was not addressed.

More importantly than offering treatment, the Vagrancy Act was expected to be an instrument to guard society against the supposed threat represented by vagrants and alcoholics. ${ }^{42}$ Getz explained that 'the professional criminal, the vagrant, alcoholic and drifter', who abused their freedom, had to be confined for thorough treatment if any behavioural change could be expected. Only thus could they be allowed to enjoy freedom. The argument of treatment was present, but the medicine was apparantly workhouse detention. Nevertheless, Getz was not optimistic and rather emphasised how detention at least facilitated the function of incapacitation: 'though the prospect of rehabilitation in general is

Act 1900-5-31 on the prison service and forced labour (Lov om Fængselsvæsenet og om Tvangsarbeide), $₫ 50$. This act was revised and passed again 12.12.1903 in connection with the implementation of the Penal Code of 1902. Regarding workhouses, there were only minor changes.

$39 \quad$ Stortingets forhandlinger (1898/1899): Ot.prp. 2. p. 11.

$40 \quad$ Forhandlinger ved Den norske Kriminalistforenings tredie møde i november 1894 (Aschehoug 1895) pp. $26 \mathrm{ff}$. When the bill was sent out for comments, a bailiff (fogd) argued against the bill because he rather recommended the state to establish institutions for chronic alcoholics in which they could receive treatment. (Stortingets forhandlinger (1898/1899): Ot.prp. 2. p. 7).

41 Act 1900-5-31 on the prison service and forced labour (Lov om Fængselsvæsenet og om Tvangsarbeide), $\$ 50$.

$42 \quad$ Getz 1893 p. 118. 
meagre, at least the society for a longer or shorter period is liberated from the vagrants. ${ }^{43}$ This pessimism was substantiated by warnings that workhouses had a very negative influence upon the inmates, especially those not yet hardened and considered incorrigible. The chief of police in Bergen, Julius Olsen (1848-1935), explained in a response to the draft in 1895 that workhouses were not institutions for improvement or rehabilitation, but 'rather the opposite, as those who once are found qualified for workhouse detention normally become habitual inmates. ${ }^{4}$

When Getz discussed indefinite sentences in 1894, he distinguished between habitual criminals and dangerous criminals. He expected that the Vagrancy Act would deal with the habitual criminals, those who frequently committed petty crimes and thefts leading to short sentences. For these bothersome criminals it would be sufficient to sentence them to workhouse detention for 3-6 years. ${ }^{45}$ Indefinite sentences, however, were meant for 'particularly dangerous criminals'. But these dangerous criminals could also be incarcerated in workhouses alongside vagrants and chronic alcoholics, reflecting meagre optimism regarding the rehabilitation of vagrants. ${ }^{46}$

In order to justify lengthy workhouse detentions, Getz did not redefine the sanction from a punishment to help or treatment, like others did. Getz' general opinion was that punishment could only be a result of a legal violation. Thus, he chose to criminalise the situations described in the poor law; 'Only by proclaiming vagrancy as criminal and liable to punishment, could extensive detentions be justified. ${ }^{47}$

Getz argued that vagrants neccesarily were a danger to private property, public order and safety in general and at they consequently were liable to punishment. This introduced a principle of punishment based on suspicion, which was controversial among contemporaries of Getz. He rejected such criticism, claiming that no injustice was done to vagrants 'because it is unquestionable that they are punishable criminals, even though no specific crime can be proved. ${ }^{48}$ Intoxication, Getz continued, was not an offence in itself. But it was recognised that intoxication was a vice which could cause danger to others or to society in general, and therefore it was justifiable to label it as punishable. The society was allowed to protect itself against the inconveniences caused by intoxication.

43 Bernhard Getz quoted in Forhandlinger ved Den norske Kriminalistforenings tredie møde $i$ november 1894 (Aschehoug 1895) pp. 13 ff.

44 NNA: S-3212 Justisdepartementet, Lovavdelingen, De. Strafferett. Prosess. Frigjøring og rettsoppgjør. L 0080-001/002/1003 (Erklæringer angående utkast til lov om løsgjengeri, politimesteren i Bergen).

45 Forhandlinger ved Den norske Kriminalistforenings tredie møde i november 1894 (Aschehoug 1895), p. 130.

46 Udkast til Lov om Løsgjongeri, Betleri og Drukkenskab samt om Tvangsarbeidshuse (1894), paragraph 40.

$47 \quad$ Udkast til Lov om Løsgjongeri, Betleri og Drukkenskab samt om Tvangsarbeidshuse (1894), p. 17.

$48 \quad$ Getz 1893 p. 122. 
By defining certain lifestyles, not just certain acts, as criminal, sanctions against vagrants were considered implementable without violating the Constitution.

The substantial infringement in individual freedom was thus justified by describing vagrants and chronic alcoholics as recidivists who were not susceptible to improvements, at least not without long-lasting detentions. Thus they could be subjected to a particular internment, otherwise considered completely out of proportions. The maximum sentence for first-time detention was 18 months, and as much as three years if repeated. In some cases this could be extended to six years. Necessary for detention was a conviction in court, but the decision to detain in a workhouse as an alternative or in addition to a jail sentence, was delegated to the prosecution service. The reason for delegation was the assumption that officers within the police were better qualified to make the decision because of their better street-knowledge of the convicted vagrant. ${ }^{49}$ In his draft, Getz went even further and suggested that all releases from workhouses were to be on parole. ${ }^{50}$ If the conditions for release were violated, the draft granted the police a discretionary power to redetain for as much as two more years. Once convicted, that would have provided the police discretionary power to prolong detentions perpetually. This proposal was considered too radical by the Ministry of Justice and parliament. ${ }^{51}$

The motivation for reforming the legislation regarding vagrants and the workhouse system, including the introduction of a judiciary process, was to bring the legislation in compliance with prevailing principles of the rule of law. An additional motivation was to detach the 'unrespectable' paupers from the Poor Law in order to lessen the stigma of poor relief among unemployed workers, as the concept of unemployment had changed in the latter part of the nineteenth century. This legal modernisation was regarded as inevitable, according to many administrators of the forced labour system, but also deplorable because it obstructed a practice considered to be both efficient and useful for social control.

Getz seemed to have little faith in workhouses as instruments to facilitate treatment and rehabilitation of vagrants and alcoholics. But society needed a strong instrument to incapacitate and render harmless habitual petty criminals who allegedly threatened private property. The target groups of the Vagrancy Act were not only seen as a nuisance in public space, but were also assumed to be a physical threat to random members of the public. The Vagrancy Act aimed to prevent by incapacitation, not by treatment or moral improvement. Shortly before his death in 1901, Getz emphasised the important function

49 Stortingets forhandlinger (1898/1899): Indst.O.XIX. p. 5, og Stortingets forhandlinger (1898/1899): Ot.prp. 2. p. 15.

$50 \quad$ Udkast til Lov om Løsgjoengeri, Betleri og Drukkenskab samt om Tvangsarbeidshuse (1894) §33 p. 10 .

51 Stortingets forhandlinger (1898/1899): Ot.prp. 3. p. 31 and Act 1900-5-31 on the prison service and forced labour (Lov om Fængselsvæsenet og om Tvangsarbeide), $₫ 54$. 
of workhouses towards petty criminals, when a judge voiced concern that the short prison sentences which the new criminal code authorised against petty crime would neither be a deterrence nor provide incapacitation towards the 'scum of society. ${ }^{52}$

Thus it can be argued that Getz balanced different discourses - a medical discourse emphasising the function of treatment on one hand and a discourse emphasising the function of social renovation and property protection on the other - as strategies for mounting support both within penal professions and the political sphere. The function of treatment could be promoted as economically advantageous to society because it reduced crime in the long run, but at the same time expenses for treatment had to be minimalised. Consequently, the actual content of treatment was limited and building institutions for treating chronic alcoholism was made voluntary.

Though some of Getz' contemporaries conveyed more optimism regarding prospects for treatment, the Vagrancy Act was heavily marked by Getz' point of view. It represented procedural changes prior to detention, but the target group and the core function of interment continued. Though alcoholism was regarded as a disease, the vagrants and chronic alcoholics were mainly considered as threats to social order and public security, not as patients. The extended time of interment authorised under the new act made it practically a continuation of its predecessor. Flexible procedures under the Poor Law, in which the police were authorised to decree detention without a legal recourse, made it possible for very swift returns to the workhouse, often only a few days after release. ${ }^{53}$ The prolonged period of detention can be regarded as a compensation for the more bureaucratic procedures which came with judicial decisions.

The Vagrancy Act kept as much of the discretionary powers as possible, without formally breaching the principle of legality. Effectively, the act was marked by a dual jurisprudence. On the one hand, individual liberties were strengthened as the rule of law and due process guaranteed the interests of 'respectable' citizens, while arbitrary and extra-judicial interventions were legitimised as deterring and incapacitating measures against the 'residuum' who represented a threat to the social order. Thus, the penal reforms around 1900 represented a continuity in the policy towards those who failed to present themselves as available workforce.

52 Concern was voiced at a meeting in the Norwegian Criminalist Association in 1901 by Judge Hausman, and Getz replied to his concerns. Forhandlinger ved Den Norske Kriminalistforenings sjette møde i Januar 1901, udgivne af Francis Hagerup, (Aschehoug 1901), pp. 75-78.

53 Ulvund, 'at rense gaterne' Tvangsarbeid som disiplinering og sosial kontroll før 1907, in Virker straff?, ed. Olsen (Scandinavian Academic Press 2012), p. 73. 
Frode Ulvund

\section{Terminating the idea of treatment}

The Vagrancy Act was sanctioned by the King 31 May 1900, but did not come to force until 1 August 1907. In the mean-time, the regulations of the Poor Law continued to authorise workhouse detentions and the old workhouses were still in use. Despite the long period of time between the adoption and the implementation of the act, the infrastructure was still completely inadequate by 1907. No new state workhouses had been established, not to mention any curative institutions. A commission had been appointed to estimate what workhouse capacity was required as a consequence of the new Vagrancy Act. According to them, the main purpose of the workhouse was not to facilitate rehabilitation or treatment, but to detain vagrants so that the society 'got rid of them for a shorter or longer period. ${ }^{54}$ Consequently, the commission argued that new institutions should be built as inexpensive as possible. The commission failed to mention curative institutions at all, but they suggested to classify inmates by separating young offenders into separate institutions in which rehabilitation should be especially facilitated. ${ }^{55}$ For the older group of habitual criminals, vagrants and alcoholics - the main target group - they argued there was no need to make any sacrifices as they had no hope for their improvement. By the time the Vagrancy Act entered into force, incapacitation and rendering the subjects harmless was left as the the only actual function of the detentions.

The practice of discretionary internment was more explicitly continued for female detainees. Historian Karoline Hille has demonstrated how female workhouse inmates under the Vagrancy Act were subjected to substantial incarceration as a result of discretionary powers excercised outside the framework of prosecutors or the judiciary. ${ }^{56}$ From 1907, the court could delegate to the prosecutor the decisive power of whether or not to detain a female subject in a workhouse in the same manner as men. But as an alternative to workhouses, the prosecuting authority could place women in a 'Sheltered Women's House' (Kvinnehjem). If the women demonstrated good behaviour for a year or two, they could be released without receiving a workhouse detention. But if the women escaped, or the board of the Women's House considered their behaviour inappropriate, the women could be transferred to a workhouse to serve their workhouse sentence in full. Female workhouse detainees could also be released on parole if they entered a Women's House, but could be returned to the workhouse if the board was not satisfied for some reason. Hille argues that a conviction authorised under the Vagrancy Act therefore resembled a sword hanging over the convicted woman's heads for up to ten years, depend-

54 Om istandbringelse af nye tvangsarbeidsanstalter: indstilling fra den af Justisdepartementet 28de september 1905 nedsatte komite (1907), p. 9.

$55 \quad$ Ibid., pp. $5 \mathrm{ff}$.

56 Hille, Kvinner dømt til tvangsarbeid. En studie av kvinner dømt etter løsgjengerloven i Norge 1907-1938, Master thesis (University of Bergen 2013), pp. $121 \mathrm{ff}$. 
ing on their age. The consequence was an extreme encroachment in these women's civil liberties which were managed outside the judiciary, without transparancy to the public, and also for a large part outside the public prosecutor's hands. Hille also claims that the authorities were not especially interested in evaluating the effects of treatment or rehabilitation for these female detainees. This was most striking when it came to offenders who hade been placed in Women's Houses, where the employees had no adequate education or professional background qualifying them to facilitate treatment.

\section{Concluding remarks}

The main purpose of forced labour authorised in the Poor Laws, and later in the Vagrancy Act, already from their adoption, was primarily societal defence in the form of social renovation and incapacitation. The advent of judicial procedures prior to detention from 1907 limited the police's scope of action to such an extent that it was soon perceived as a problem within the force. The powerful 'warship' - as the Vagrancy Act initially was labelled, meant to deter vagrants, soon ran aground. The encroachment in police powers as a result of the judiciary process reduced the number of detentions substantially. Consequently, the legislation was later (in 1918) adjusted in order to better facilitate the task of incapacitation which the legislation was meant to fulfil. ${ }^{57}$

The penal reforms were marked by two preventive pillars; treatment and the incapacitation of potential criminals. In the discourse regarding vagrancy, both these two pillars were reflected. That was far from exceptional among the penal reform bills. The motive of renovation and incapacitation was however definitely most distinctly articulated when it came to vagrancy. The Children's Bill was bestrewed with rhetorical emphasis on prevention through treatment. The formal name of the bill, which the act kept, also included the notion 'treatment' in order to distance it from traditional discourse of punishment. Nevertheless, as Tove Stang Dahl (1938-1993) has demonstrated, even the Children's Bill was motivated by societal protection..$^{58}$ She claimed that an important background for the Children's Bill was to facilitate a new school law which promoted a public school for all children, regardless of social background. The Act was expected to be a pivotal instrument in segregating certain troublesome children from public schools. Bernhard Getz was well aware of the political and social challenges caused by the school reform unless efficient means of segregation were provided for. He explained that school boards would not allow access to schools for children who were feared to represent a moral danger to

57 Cf. Larsen, Mellom moral og medisin. Løsgjengerlovens tilblivelse og tilpasning 1900-1918, Master thesis (University of Bergen 2005) for the history of legal adjustment of the vagrancy Act.

58 Dahl, Barnevern og samfunnsvern. Om stat, vitenskap og profesjoner under barnevernets oppkomst i Norge, (Gyldendal 1994 [1978]) pp. 120 ff. 
other children..$^{59}$ The Board of Guardians, established by the Children's Act, carried out such a function of segregation in which societal needs were considered, and not the children who were subjected to coercive measures.

The Vagrancy Act, as well as the Criminal Code of 1902 and the Children's Act, must be analysed with these two pillars in mind. They were all part of one system, as Getz explained. Prevention was pivotal, either through treatment or by rendering the target group harmless. Incapacitation and renovation were the core functions of workhouse detentions under the regime of the Poor Law, and this continued when such detentions were authorised by the Vagrancy Act. Treatment was a subordinate motive when the bill was prepared, and even more so when the act was finally implemented from 1907. This also reflected a reconceptualisation of unemployment as a result of rapid industrialisation and the demand for a mobile workforce. As a consequence, it was necessary to distinguish between those who made themselves available as workforce, and should be helped, and those who were regarded as unwilling, and who should be subjected to coercive measures.

Professionalisation and a more scientific approach in the penal system led to increased complexity in what David Garland referred to as penal culture. ${ }^{60}$ Different voices emphasised different aspects of the two pillars of prevention. That resulted in different discursive practises, either because different professional groups were marked by distinct discursive traditions, or because certain participants mastered a discursive repertoire which efficiently enabled them to gain political and professional support for reforms. The latter was demonstrated by Bernhard Getz in his reform project which was crowned with the Penal Code of 1902.

59 Forhandlinger ved Den norske Kriminalistforenings tredie møde i november 1894 (Aschehoug 1895) p. 2.

60 Garland, Punishment and Modern Society. A Study in Social Theory (Oxford University Press 1990) pp. 196 ff. 